\title{
Impact of body mass index and low estrogen level on urinary hydroxyl proline and other bone related parameters in postmenopausal women
}

\author{
${ }^{1}$ Department of Biochemistry, MGM Medical College, Indore, Madhya Pradesh, India \\ ${ }^{2}$ Department of Pathology, MGM Medical College, Indore, Madhya Pradesh, India \\ ${ }^{3}$ Department of Biochemistry, SAMS Medical College, Indore, Madhya Pradesh, India \\ ${ }^{4}$ Department of Gynecology, MGM Medical College, Indore, Madhya Pradesh, India
}

Sangita Paneri ${ }^{1}$, Ashok Panchonia ${ }^{2}$, Meena Varma $^{3}$, Purnima Dey Sarkar $^{1}$, Sumitra Yadav $^{4}$

Received: 5 March 2014

Accepted: 25 March 2014

*Correspondence:

Dr. Sangita Paneri,

E-mail: drsanlit@yahoo.com

(C) 2014 Paneri S et al. This is an open-access article distributed under the terms of the Creative Commons Attribution Non-Commercial License, which permits unrestricted non-commercial use, distribution, and reproduction in any medium, provided the original work is properly cited.

\begin{abstract}
Background: The study revealed the impact of body mass index and low estrogen level on urinary hydroxyl proline and other bone related parameters in postmenopausal women.

Methods: The study comprised 145 obese postmenopausal women and 145 ideal weight postmenopausal women as a study subjects and 145 normal reproductive age group women taken as control. The following biochemical parameters serum calcium, serum phosphorous, serum alkaline phosphatase, urinary calcium, urinary creatinine, urinary hydroxyproline were estimated for assessment of bone loss. Then these results were compared with control group.

Results: The significant changes found in biochemical parameters in ideal weight postmenopausal women and highly significant changes in biochemical parameters observed in obese post menopause women.

Conclusions: The obese postmenopausal women who have high BMI and low estrogen level have higher bone loss and are more prone to suffer from bone related problems.
\end{abstract}

Keywords: Post-menopause, Hydroxyproline, Calcium, Bone loss, Osteoporosis, BMI

\section{INTRODUCTION}

Bone is made up of inorganic minerals like calcium, phosphorus magnesium and organic matrix like protein and collagen. The bone formation process (osteoblastic activity) and bone resorption process (osteoclastic activity) occurred simultaneously. During bone resorption first calcium and phosphorous released and then collagen degradation product hydroxyproline released. ${ }^{1,3}$ These minerals of bone are affected by various hormone (like PTH, calcitonin, estrogen ) and age. After age of 40-50 years cortical bone is lost at a rate of about $0.3-0.5 \%$ per year. ${ }^{6}$ In postmenopausal stage the decrease in bone mineral density seen which results in to development of bone related diseases like osteoporosis. The risk of osteoporosis is higher in obese postmenopausal women. In order to study the relationship between estrogen depletion, obesity and bone loss, this study was planned, so that we can find out the pattern of biochemical changes in bone related parameters for assessment of bone loss in postmenopausal women which can help the clinician's to treat this bone loss timely and minimizes the chances of osteoporosis and other bone related problems of normal weight postmenopausal and obese postmenopausal women.

\section{METHODS}

The present study was conducted in department of biochemistry, MGM medical college, Indore. 145 healthy 
ideal weight reproductive age woman taken as control and 145 ideal weight postmenopausal women and 145 obese postmenopausal women taken as study group I and II respectively.

\section{Exclusion criteria}

Subjects with history of smoking, alcohol intake, chronic illness, surgically induced menopause and women taking HRT were excluded from study.

Venous blood collected from each subject for estimation of following biochemical parameters by fully automated biochemistry analyzer - serum calcium, serum phosphorous, serum alkaline phosphate, serum total protein, serum albumin.

Urine sample collected from each subject for estimation of urinary calcium - (Arsenoz III method), urinary creatinine - (Modified Jaff's Method), urinary hydroxyproline by modified (Neman and Logan method).

The statistical analyses were done in which Mean, SD, Student t-test and P values were calculated.

\section{RESULTS}

Table 1 shows comparison of biochemical parameters between control and ideal weight postmenopausal women (study group-I). Table 2 shows comparison of serum biochemical parameters between control and obese weight postmenopausal women (study group-II). Table 3 shows comparison of serum biochemical parameters between control and obese weight postmenopausal women (study group-II).
Table 1: Comparison of biochemical parameters between control and ideal weight postmenopausal women (study group-I).

\begin{tabular}{|lll|l|}
\hline Parameters & $\begin{array}{l}\text { Control } \\
\mathbf{n}=\mathbf{1 4 5}\end{array}$ & $\begin{array}{l}\text { Study } \\
\text { group I } \\
\mathbf{n}=\mathbf{1 4 5}\end{array}$ & P value \\
\hline $\begin{array}{l}\text { Serum calcium } \\
\text { (mg/dl) }\end{array}$ & $10.8 \pm 1.2$ & $9.1 \pm 1.6$ & $*<0.05$ \\
\hline $\begin{array}{l}\text { Serum phosphorus } \\
\text { (mg/dl) }\end{array}$ & $3.5 \pm 0.8$ & $2.9 \pm 0.6$ & $*<0.05$ \\
\hline $\begin{array}{l}\text { Serum alkaline } \\
\text { phosphates (U/L) }\end{array}$ & $140 \pm 32$ & $228 \pm 46$ & $* *<0.001$ \\
\hline $\begin{array}{l}\text { Serum total protein } \\
\text { (g/dl) }\end{array}$ & $6.4 \pm 1.3$ & $6.2 \pm 1.2$ & NS \\
\hline $\begin{array}{l}\text { Serum albumin } \\
\text { (g/dl) }\end{array}$ & $3.2 \pm 0.7$ & $3.1 \pm 0.4$ & NS \\
\hline
\end{tabular}

Table 2: Comparison of serum biochemical parameters between control and obese weight postmenopausal women (study group-II).

\begin{tabular}{|llll|}
\hline Parameters & $\begin{array}{l}\text { Control } \\
\mathbf{n}=\mathbf{1 4 5}\end{array}$ & $\begin{array}{l}\text { Study } \\
\text { group II } \\
\mathbf{n = 1 4 5}\end{array}$ & P value \\
\hline $\begin{array}{l}\text { Serum calcium } \\
(\mathrm{mg} / \mathrm{dl})\end{array}$ & $10.8 \pm 1.2$ & $8.6 \pm 1.32$ & $* *<0.001$ \\
\hline $\begin{array}{l}\text { Serum phosphorus } \\
(\mathrm{mg} / \mathrm{dl})\end{array}$ & $3.5 \pm 0.8$ & $2.9 \pm 0.6$ & $* *<0.001$ \\
\hline $\begin{array}{l}\text { Serum alkaline } \\
\text { phosphates (U/L) }\end{array}$ & $140 \pm 32$ & $348 \pm 68$ & $* *<0.001$ \\
\hline $\begin{array}{l}\text { Serum total protein } \\
(\mathrm{g} / \mathrm{dl})\end{array}$ & $6.4 \pm 1.3$ & $6.2 \pm 1.4$ & $\mathrm{NS}$ \\
\hline $\begin{array}{l}\text { Serum albumin } \\
(\mathrm{g} / \mathrm{dl})\end{array}$ & $3.2 \pm 0.76$ & $2.9 \pm 0.6$ & $\mathrm{NS}$ \\
\hline
\end{tabular}

Table 3: Comparison of serum biochemical parameters between control and obese weight postmenopausal women (study group-II).

\begin{tabular}{|llllll|}
\hline Parameters & Control & Study I & P value & Study II & P value \\
\hline Hydroxyproline (mg/24 hr urine) & $19.8 \pm 3.8$ & $26.41 \pm 28$ & $* *<0.001$ & $42 \pm 4.2$ & $* *<0.001$ \\
\hline Creatinine (mg/24 hr urine) & $1189 \pm 128.4$ & $882 \pm 126.2$ & $* *<0.001$ & $762 \pm 118.6$ & $* *<0.001$ \\
\hline Calcium (mg/24 hr urine) & $122.81 \pm 12.8$ & $102 \pm 22$ & $* *<0.001$ & $96.4 \pm 37$ & $* *<0.001$ \\
\hline
\end{tabular}

The significant decrease observed in serum calcium and phosphorus level in ideal weight postmenopausal women and highly significant decrease observed in serum calcium and phosphorous level in obese postmenopausal women when compared to control.

- The serum alkaline phosphatase level found to be increase significantly in both study group I \& II when compared to control.
- The urinary hydroxyproline level found to be significantly increased in both study group I \& II when compared to control.

- The urinary hydroxyproline level found to be increase significantly in both study group I \& II and urinary calcium and creatinine level found to be decreased in both study group I \& II when compared to control. 
- The study showed highly significant changes in all biomedical parameters in study group II.

\section{DISCUSSION}

Urinary hydroxyproline, urinary calcium and creatinine are the most important measurement of bone resorption. In our study, we found significant and highly significant rise in urinary hydroxyproline level in ideal weight postmenopausal women and obese postmenopausal women. This indicate the increase bone loss and lower absorption of calcium from intestine in post menopause age and this bone loss was higher in obese postmenopausal woman because of low estrogen and high BMI study by Prince L et al. reported weight bearing exercise slow the bone loss and lack of this types of exercise leads to obesity and higher bone loss in postmenopausal women ${ }^{8,9,10}$.

Evidence support that the estrogen in women protect the bone loss thats why the reproductive age women are at lower risk of osteoporosis and post-menopausal women are at high risk of osteoporosis and bone loss. ${ }^{2,4}$

Thus the estimation of bone related parameters serve as a complete profile of assessment of bone loss. The significant changes in bone related parameters in postmenopausal women and obese postmenopausal women shows these women subjects are at high risk of osteoporosis. ${ }^{5}$ This study concluded high body mass index and low estrogen level both increases bone loss many folds. This study suggest that the obese postmenopausal women should exercise more to lower their BMI and routinely investigate their bone profile for assessment of bone loss so as to treat this bone loss timely to minimize risk of further complications.

Funding: No funding sources

Conflict of interest: None declared

Ethical approval: The study was approved by the institutional ethics committee

\section{REFERENCES}

1. Calvo MS, Eye DR, Gundbery M. Molecular basis and clinical application of biochemical markers of bone turnover. Endocrine Rev. 1996;17:333-68.

2. Etunger B, Genant HK, Cann CE. Postmenopausal bone loss is prevented by treatment with low dosage estrogen with calcium. Ann Intern Med. 1997; $106: 40-5$

3. Garnero P, Delmar PD. New developments in biochemical markers for osteoporosis. Calif Tissue Int. 1996;59(Suppl 1):52-9.

4. Genant H.K, Cann CE, Etinger B et al. Quantitative CT of vertebral spongiosa: a sensitive method for detecting early bone loss after oophorectomy. Ann Intern Med. 1982;97:699-705.

5. Johnson CA, Corrigan SA, Dubbert PM et al. Perceived barriers to exercise and weight control practices in community women. Women Health 1990;16:177-91.

6. Krane SM, Holick MF. Metabolic bone disease In: Braunward E, Isselbacher KJ, Fauci AS, Karper DL, eds. Harrison's Principles of Internal Medicine, 13th ed. New York: McGraw Hill; 1994: 2172-2183.

7. Mitoma C, Smith TE, Davidson JD, Udenfriend S, Delolta M, Sperdoma A. Improvements in methods for mea swing hydroxyproline. J Lab Clin Med. 1959;53:970-6.

8. Prince RL. Smith M. Dickim et al. Prevention of postmenopausal osteoporosis. N Eng J Med. 1991;325(17):1189-95.

9. Rankin J, Volpe S. Diet, exercise and osteoporosis, Am College Sports Med. 1998;3:1-4.

10. Riggs BL, Melton LJ. The preventive and treatment of osteoporosis. N Eng J Med. 1991;327:620-7.

DOI: $10.5455 / 2320-1770$. ijrcog20140609

Cite this article as: Paneri S, Panchonia A, Varma M, Sarkar PD, Yadav S. Impact of body mass index and low estrogen level on urinary hydroxyl proline and other bone related parameters in postmenopausal women. Int J Reprod Contracept Obstet Gynecol 2014;3:335-7. 